\title{
PEMBERDAYAAN MASYARAKAT PETERNAK MELALUI PROGRAM DEBEST (DESA BEBAS FESES) MENJADI BIOGAS DAN PUPUK ORGANIK KANDANG DI DESA SERADING
}

\author{
Khotibul Umam¹ ${ }^{1}$, Lili Suharli², Mikhratunnisa ${ }^{3}$ \\ 1,2Program Studi Teknobiologi, \\ ${ }^{3}$ Program Studi Teknologi Pertanian \\ Universitas Teknologi Sumbawa, Indonesia \\ Co-author: khotibul.umam@uts.ac.id
}

\begin{abstract}
ABSTRAK. Desa Serading dikenal sebagai sentra ternak Sumbawa yang memiliki potensi besar. Potensi ini karena banyaknya jumlah ternak, kelompok peternak dan sektor lain yang terlibat. Debest atau desa bebas feses merupakan inti dari program untuk mengelola feses ternak sehingga dapat dioptimalkan menjadi produk yang bermanfaat. Pelaksanaan pengabdian ini bertujuan untuk memberikan pendampingan dalam memberdayakan masyarakat peternak di desa serading untuk mengelola peternakannya secara integrative. Akan ada banyak manfaat dan sektor yang terdampak positif dengan pengelolaan berbasis bioteknologi yang diterapkan masyarakat Serading, Sumbawa. Metode pelaksanaan pemberdayaan masyarakat melalui tiga tahapan yaitu pemetaan potensi, penyampaian potensi dan sosialisasi program pengabdian serta pelaksanaan workshop untuk penerapan secara langsung. Hasil yang diperoleh dari pelaksanaan pemberdayaan ini selanjutnya diukur melalui direct interview kepada sampling masyarakat. Melalui program pemberdayaan masyarakat peternak di Serading melalui prinsip bioteknologi, banyak teknologi dan produk yang bisa didapatkan masyarakat. Teknologi tersebut diaplikasikan dengan memanfaatkan feses ternak sebagai bahan utama untuk pembuatan biogas dan pupuk kandang organik (POK). Program pemberdayaan masyarakat Serading ini menunjukkan bahwa besarnya potensi ternak di desa serading berkorelasi positif dengan meningkatnya produk produk bioteknologi yang bisa dihasilkan dan dapat dimanfaatkan warga baik untuk penggunaan sendiri maupun dikomersialisasi.
\end{abstract}

Kata Kunci: peternakan terpadu,bioteknologi, pemberdayaan, serading

ABSTRACT. Serading village is known as the center of Sumbawa cattle, which has excellent potential. This potential is due to a large number of livestock, breeder groups, and other sectors involved. Debt or village free of feces is the core of the program to manage livestock feces so that it can be optimized into useful products. The implementation of this service aims to assist in empowering the community of farmers in the village of Serading to manage their farms integratively. There will be many benefits and positive impact sectors with biotechnology-based management implemented by the Serading community, Sumbawa. The method of implementing community empowerment through three stages, namely mapping the potential, delivering the potential, and socializing the service program and conducting workshops for direct implementation. The results obtained from the implementation of empowerment are then measured through direct interviews with community sampling. Through the community empowerment program for farmers in Serading through the principles of biotechnology, many technologies and products can be obtained by the community. The technology is applied by utilizing livestock feces as the primary material for making biogas and organic manure (POK). The Serading community 
empowerment program shows that the enormous potential of livestock in the Serading village is positively correlated with the increase in biotechnology products that can be produced and can be used by residents both for their use and commercialization.

Keywords: integrated animal husbandry, biotechnology, empowerment, serading.

\section{PENDAHULUAN}

Hewan ternak merupakan aset yang memilki nilai manfaat yang besar apabila dimanfaatkan secara optimal, sebaliknya sumber masalah jika dibiarkan. Sebagai daerah yang dikenal dengan program Bumi Sejuta Sapi (BSS), Pulau Sumbawa menyumbangkan aset ternak yang besar untuk meningkatkan kesejahteraan masyarakatnya (Winarti dkk, 2015; Hidayatullah dkk, 2018). Namun hal ini menimbulkan persoalan baru karena kurangnya pengetahuan masyarakat tentang peternakan sehingga potensi ternak yang besar tidak termanfaakan secara optimal. Secara nasional, Propinsi NTB berkontribusi sebesar 14.8\% ternak (Dinas PKH NTB, 2017) yang terkonsentrasi salah satunya di pulau Sumbawa dan tersebar di beberapa kecamatan. Kecamatan moyo hilir menunjukkan tingkat dominasi yang tinggi dibandingkan dengan wilayah lainnya dalam jumlah ternak. Desa bebas feses ternak (DEBEST) adalah program yang dilaksanakan untuk pemberdayaan masyarakat peternak dengan menggunakan prinsip bioteknologi. kepada masyarakat sebagai upaya memberikan edukasi dalam mengoptimalkan potensi ternak multisektoral sehingga terasa manfaatnya tanpa adanya residu lain yang dihasilkan. Salah satu Desa yang tercakup di dalamnya adalah Desa Serading yang secara administratif berada di bawah Kecamatan Moyo Hilir, Kabupaten Sumbawa. Desa ini terdiri dalam 5 dusun yang memiliki 30 RT dan $10 \mathrm{RW}$ dengan luas desa 26,24 km² (sumber wawancara, 2018). Sebagai wilayah dengan persentase peternak yang dominan di samping bertani, masyarakat Desa Serading umumnya menggunakan pola beternak secara ekstensif yakni ternak digembalakan di luar kandang atau dilepas liar ke alam. Pola peternakan ekstensif inilah yang perlu diberikan perhatian lebih karena dampak yang ditimbulkannya ke masyarakat dan lingkungan sekitar. Aktifitas hewan ternak yang dibiarkan oleh pemiliknya telah menimbulkan persoalan estetika lingkungan dengan kotoran yang berserakan, sumber penyakit menjadi tersebar, tingkat pemanasan akibat gas metana yang dilepaskan, penggunaan pupuk kandang tidak optimal dan pakan sangat tergantung musim sehingga ternak merambah ke tanaman pertanian yang berujung terjadinya pergesekan antar masyarakat. Oleh karena itu program DEBEST menawarkan solusi yang berpusat pada sektor peternakan sebagai core program dan tersinergi dengan sektor lainnya seperti sektor pertanian, kesehatan masyarakat dan ternak, ketahanan energi, teknologi pakan, dan perekonomian masyarakat baik dari peningkatan produksi. DEBEST menggunakan beberapa teknologi rekayasa hayati (bioteknologi) yang cukup sederhana bertujuan untuk kemudahan penerapan bagi masyarakat desa. Sebagai program yang memiliki nilai kebaruan, DEBEST dapat menjadi salah satu upaya peningkatan potensi peternakan yang efektif sehingga hasil yang optimal dapat dirasakan secara langsung oleh masyarakat. Beberapa teknologi berbasis bioteknologi yang diaplikasikan dalam kegiatan pemberdayaan di Desa Serading yaitu Biogas portable dan Pupuk organic kandang (POK).

\section{ANALISIS PERMASALAHAN}

Persoalan yang terdapat di desa Serading umumnya adalah peternakan yang dilakukan secara ekstensif yakni ternak digembalakan secara lepas liar. Peternakan dengan model seperti ini memberikan dampak dari feses ternak yang berserakan di mana mana. Masyarakat desa yang 
terbiasa dengan kondisi seperti ini akan menganggap biasa biasa saja, namun persentase masyarakat yang merasa risih dengan feses yang berserakan ini cukup banyak juga (tabel 1).

Tabel 1. Persepsi masyarakat serading terhadap feses ternak berserakan

\begin{tabular}{ccccc} 
Persepsi & \multicolumn{3}{c}{ Juni } & \multicolumn{2}{c}{ Juli } \\
\hline Biasa saja & 12 & $60 \%$ & 8 & $40 \%$ \\
Risih & 5 & $25 \%$ & 7 & $35 \%$ \\
Lainnya & 3 & $15 \%$ & 5 & $25 \%$
\end{tabular}

Tabel menunjukkan bahwa persepsi masyarakat yang rishi, meskipun tidak lebih banyak dari yang merasa biasa saja dengan feses ternak berpotensi menjadi masalah serius yang harus segera diselesaikan. Sehingga program pemberdayaan masyarakat peternak untuk mengelola feses menjadi barang bermanfaat diharapkan dapat menjaadi solusi efektif.

\section{SOLUSI YANG DITAWARKAN}

Pemberdayaan masyarakat peternak melalui mekanisme peternakan terpadu berbasis prinsip bioteknologi adalah solusi yang bisa ditawarkan. Feses ternak sebagai sumber masalah dapat dioptimalkan fungsinya menjadi produk inovasi yang dapat memberikan manfaat secara langsung kepada masyarakat. Penawaran solusi untuk menyelesaikan persoalan ini, dapat dilakukan melalui beberapa tahapan berikut :

\section{Pemetaan potensi Desa}

Pemetaan potensi desa dilakukan dengan kunjungan awal ke desa serading untuk penjajaakan sebagai desa pengabdian. Pemetaan dilakukan dengan diskusi langsung antara pelaksana dan pihak desa maupun observasi lapangan.

\section{Pelaksanaan pelatihan dan demonstrasi pembuatan biogas}

Pemberdayaan masyarakat untuk menghasilkan gas dari feses ternak sangat efektif untuk tipikal masyarakat pedesaan seperti Serading. Umumnya masyarakat memenuhi kebutuhan energy dengan menggunakan gas elpiji atau minyak tanah dan kayu bakar. Dengan prinsip fermentasi feses yang ditempatkan pada kotak digester akan menghasilkan gas metan yang dapat disalurkan langsung ke kompor yang dimodifikasi. Demonstrasi sekaligus juga dengan pendampingan untuk mengajarkan masyarakat bagaimana mengubah feses menjadi biogas.

\section{HASIL DAN PEMBAHASAN \\ Survei Lokasi}

Survei lokasi merupakan langkah awal untuk mengetahui kondisi masyarakat di setiap dusun yang ada di desa Serading. Survei dilakukan dengan cara wawancara langsung kepada perangkat desa, perangkat dusun dan penduduk. Dari hasil survey diketahui bahwa desa Serading memiliki jumlah penduduk sebanyak 4.637 jiwa. Penduduk desa Serading tersebar di 5 dusun yaitu dusun Serading, Karang Jati, Ai Nunuk, Ai Puntuk, dan Pelita. Luas tanah yang dijadikan lahan pertanian sebesar $1.678 \mathrm{Ha}$. Pada umumnya, penduduk desa Serading memiliki mata pencaharian sebagai petani. 


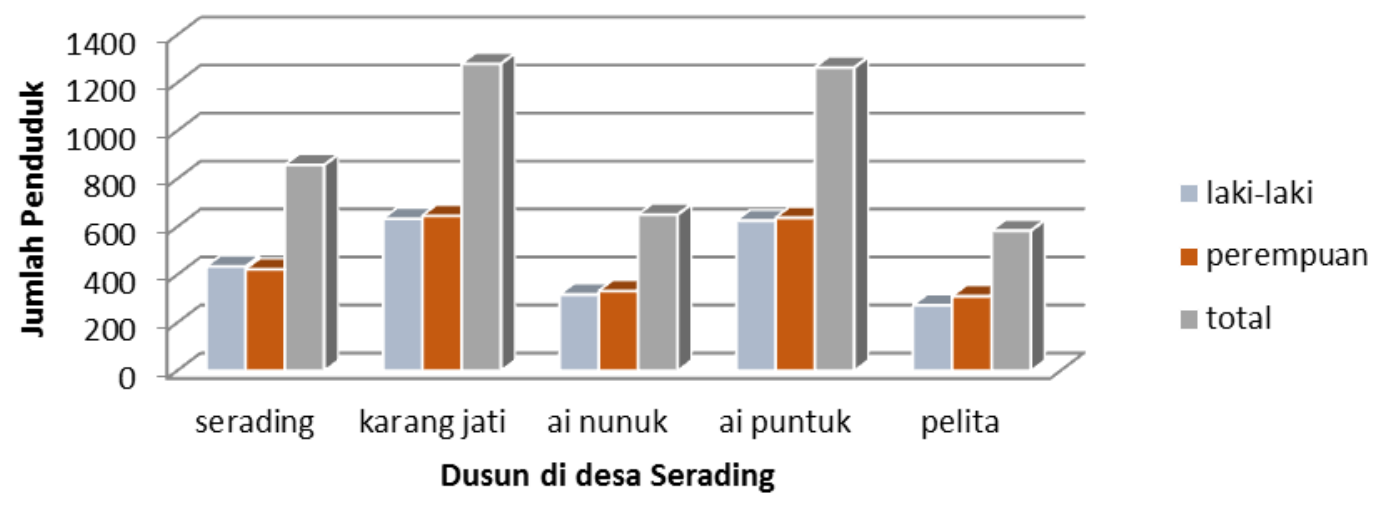

Gambar 1. Tingkat persebaran masyarakat berdasarkan jenis kelamin di tiap dusun

Desa Serading memiliki jumlah hewan ternak terbanyak di Sumbawa mencapai 4.262 ekor. Pada umumnya, masyarakat memelihara hewan ternak berupa sapi, kerbau, dan kuda. Dari sekian ribuan ternak yang ada, sampai saat ini hanya terdapat dua kelompok ternak yang aktif. Kedua kelompok peternak tersebut berada di dusun Serading. Sedangkan, pada keempat dusun lainnya, masyarakat secara individu memelihara dan mengelola hewan ternaknya secara mandiri. Hewan ternak milik masyarakat yang diperlihara secara mandiri dan dilepas bebas di lapangan mengakibatkan feses hewan ternak yang tersebar dimana-mana, ditemukan di lapangan, pinggir jalan, bahkan di tengah jalan raya utama. Feses hewan ternak dengan sengaja tidak diolah dan tidak dimanfaatkan oleh masyarakat. Feses ternak tersebut dapat menjadi tempat berkembang biak bakteri dan merusak kebersiham lingkungan.

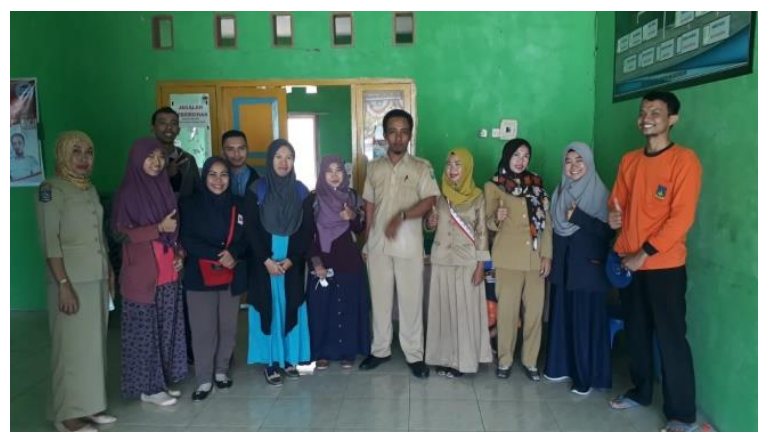

Gambar 3. Kegiatan Survey Lokasi

\section{Pendataan, verifikasi dan penetapan peserta KKN-PPM}

Kegiatan ini dilaksanakan pada minggu pertama bulan Mei 2019. Kegiatan ini meliputi seleksi dan penetapan mahasiswa calon peserta KKN-PPM 2019. Seleksi tersebut dilakukan oleh panitia KKN-PPM dalam hal ini LPPM UTS. Adapun indikator dalam penentuan mahasiswa yang lolos selekasi antara lain: 1) IPK dan jumlah SKS yang telah ditempuh, 2) Syarat administrasi yang telah ditetapkan Universitas, 3) Distribusi mahasiswa dari setiap program studi sesuai dengan yang dibutuhkan dalam kelompok, 4) disiplin ilmu yang dibutuhkan dalam KKN-PPM. Dari hasil seleksi diperoleh 32 mahasiswa yang menjadi peserta KKN-PPM 2019 di Desa Serading Kecamatan Moyo Hilir.

\section{Pembekalan Materi KKN-PPM dan Pelepasan Mahasiswa KKN-PPM}


Kegiatan ini dilakukan pada tanggal 21 Mei 2019. Pada kegiatan ini dosen pembimbing lapangan memberikan pembekalan materi seputar kegiatan KKN-PPM kepada 32 mahasiswa peserta KKN-PPM. Materi pembekalan tersebut meliputi pengelolaan potensi desa, pelatihan pembuatan prototype program, serta urgensi keberlanjutan progrman dan technopreneurship. Selain itu, pada kegiatan ini dilakukan pembagian kelompok yakni 32 mahasiswa dibagi menjadi 3 kelompok sesuai program kerja KKN-PPM. Kelompok tersebut yaitu kelompok Biogas, kelompok Pakan Silase, serta kelompok POK dan Hidroponik.

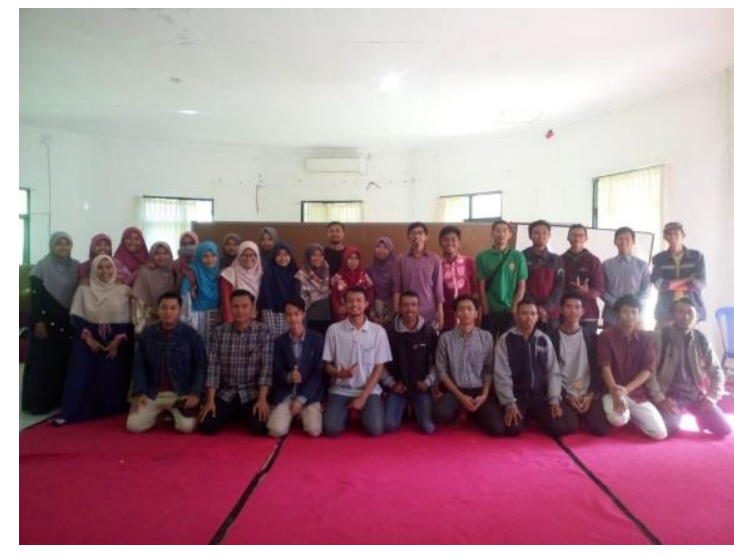

Gambar 3. Pembekalan Materi KKN-PPM

Kegiatan pelepasan KKN-PPM dilaksanakan pada tanggal 19 Juni 2019 pada pukul 090011.00 Wita dihadiri oleh Wakil Rektor I, dosen pembimbing lapangan, ketua LPPM dan panitia KKN Universitas Teknologi Sumbawa. Selanjutnya dosen pembimbing lapangan mengantarkan mahasiwa peserta KKN-PPM ke Desa Serading. Penerimaan mahasiswa peserta KKN-PPM bertempat di aula Kantor Desa Serading oleh sekretaris Desa Serading.

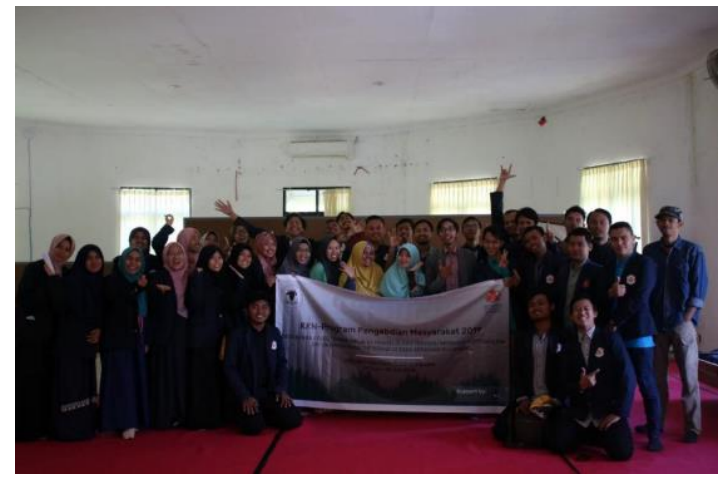

a

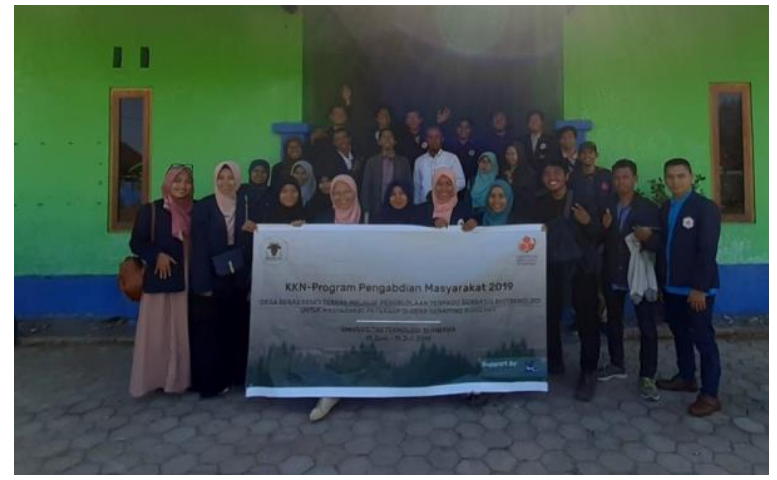

b

Gambar 4. a. Pelepasan Peserta KKN-PPM; b. Penerimaan Peserta KKN-PPM di Desa Serading 


\section{Sosialisasi Program Kerja KKN-PPM}

Kegiatan ini dilaksanakan pada tanggal 26 Juni 2019 bertempat di aula kantor Desa Serading. Pada kegiatan ini tim KKN-PPM mengundang warga dari setiap dusun yang ada di Desa Serading. Tim KKN-PPM menargetkan warga desa yang memiliki mata pencaharian sebagai petani
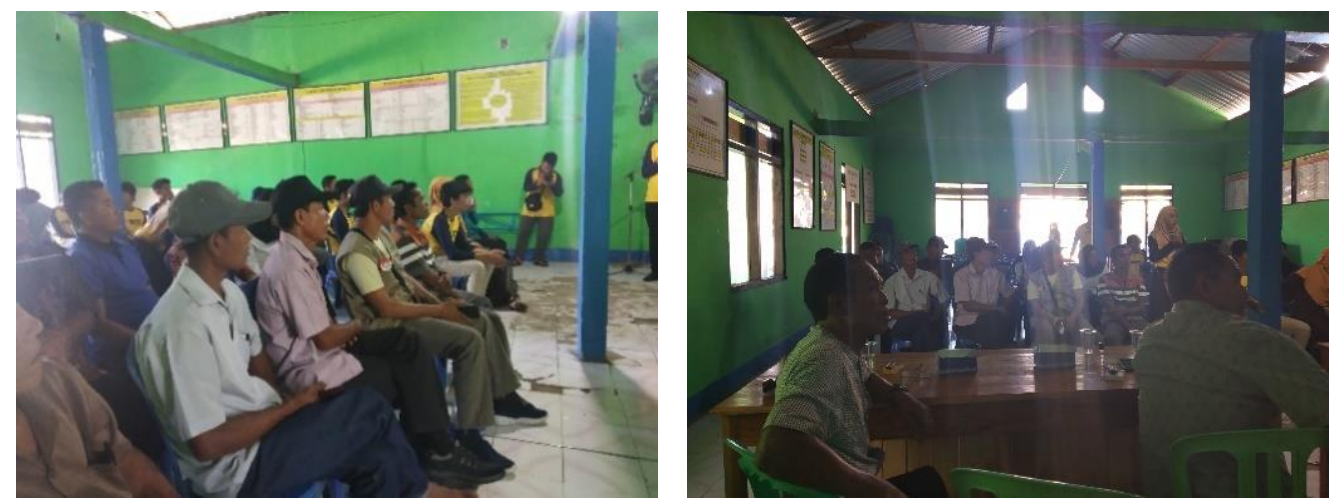

Gambar 5. Kegiatan Sosialisasi Program Debest KKN-PPM

yang memiliki hewan ternak agar dapat mengikuti kegiatan sosialisasi. Kegiatan sosialisasi ini bertujuan untuk mengenalkan program dan serangkaian kegiatan yang dilakukan selama KKNPPM. Kegiatan sosilalisasi yang dilaksanakan berhasil menarik perhatian masyarakat sebab masyarakat sangat antusias dan banyak masyarakat yang bertanya sehingga terjalin diskusi antara mahasiswa dan masyarakat desa serading.

\section{Demonstasi dan Pelatihan Program DEBEST}

Demonstrasi dan pelatihan program Debest dilaksanakan pada setiap dusun yang ada di Desa Serading yakni pada dusun Serading kegiatan dilakukan di balai pertemuan dusun Serading, pada dusun Karang Jati kegiatan dilakukan di aula kantor desa Serading, pada dusun Ai Nunuk kegiatan dilakukan di balai pertemuan dusun Ai nunuk, pada desa Ai Puntuk kegiatan dilakukan pada balai pertemuan dusun Ai puntuk, dan pada dusun Pelita kegiatan dilakukan di halaman SDN pelita. Rangkaian kegiatan ini yaitu penyampaian materi terkait program Debest yakni terkait pemanfaatan feses ternak dan limbah menjadi biogas, pakan silasi, pupuk organic kandang dan hidroponik. Selanjutnya demonstrasi dan pelatihan pembuatan biogas, pakan silase, pupuk organik kandang, dan hidroponik. Kemudian dilanjutkan dengan diskusi terkait program Debest, serta demonstrasi dan pelatihan yang telah dilakukan. Pada kegiatan demonstrasi dan pelatihan, tim KKN-PPM menyediakan prototype dan produk yang telah berhasil dibuat dan dipersiapkan beberapa hari sebelum pelaksanaan demonstrasi dan pelatihan.

\section{Demonstrasi dan pelatihan pembuatan biogas}

Biogas bukanlah hal baru dalam masyarakat karena sudah banyak sekali penerapan dan pengkajian dalam teknologi fermentasi sederhana ini. Namun keberlanjutan dari teknologi ini yang seringkali mati karena beberapa alasan seperti tidak praktis, ribet dan perlu banyak waktu akibat digester biogas yang digunakan besar (Ahmadi et al.,2016). Biogas portabel yang ditawarkan dalam DEBEST sangatlah sederhana karena menggunakan bahan bekas yang dapat di reuse seperti galon bekas. Bahkan teknologi ini bisa di moving seperti tabung gas elpiji. Bahan utama dalam pembuatan biogas adalah adalah feses ternak dan air. Fases ternak yang digunakan pada kegiatan ini adalah feses sapi, yakni feses yang baru keluar dari tubuh sapi (feses segar). Selain itu cairan EM4 menjadi bahan tambahan sebagai bakteri starter untuk mempercepat proses penguraian bahan utama menjadi produk berupa energi biru (api). Pembuatan prototype biogas menggunakan dua media yaitu botol air mineral $1,5 \mathrm{~L}$ dan drum $35 \mathrm{~L}$. Pada salah satu sisi botol air 
mineral dan drum diletakkan balon sebagai alat bantu untuk mengetahui adanya gas yang terkandung. Proses fermentasi dalam pembuatan biogas ini selama 14 - 21 hari.
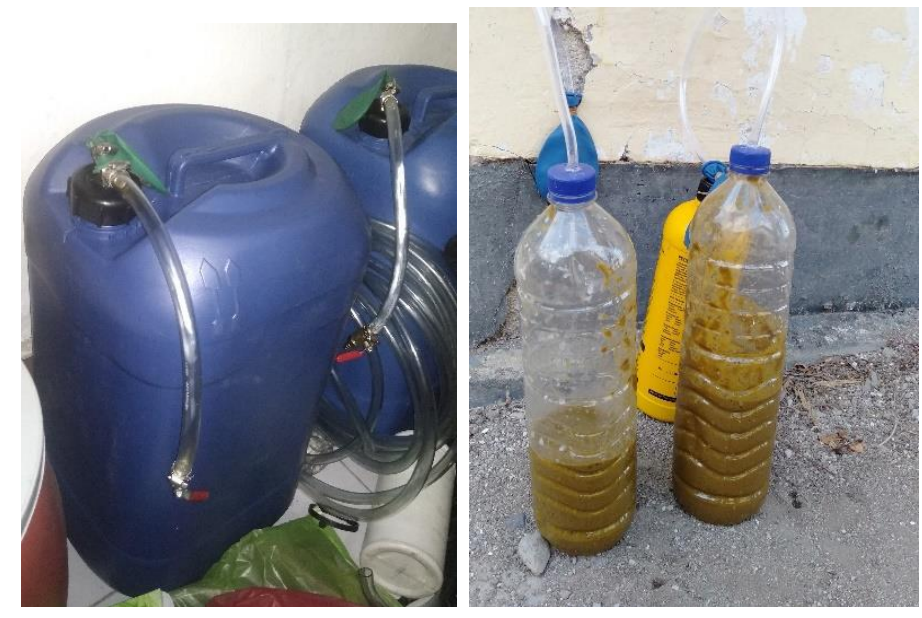

Gambar 5. Prototype Biogas

Hasil yang dicapai setelah kegiatan demonstrasi dan pelatihan pembuatan biogas antara lain masyarakat mengetahui bahwa feses ternak dapat manfaatkan sebagai untuk pembuatan biogas, masyarakat mengetahui biogas yang dihasilkan dapat digunakan untuk memasak dalam skala rumah tangga, dan masyarakat sangat antusias ingin membuat biogas untuk keperluan rumah tangga baik yang mirip dengan Prototype maupun permanen.
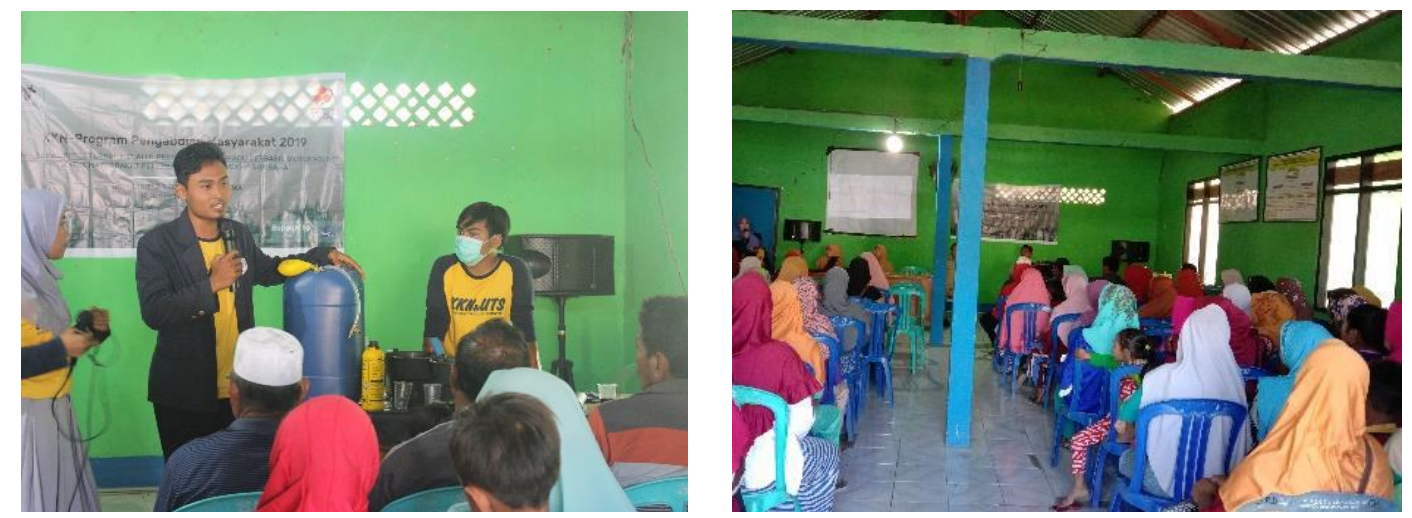

Gambar 6. Demostrasi dan Pelatihan Pembuatan Biogas

\section{Demonstrasi dan pelatihan pembuatan pupuk organik kandang (POK)}

Pupuk organik adalah trend masakini yang mulai diterapkan masyarakat karena kemudahan dalam memperoleh dan fungsinya sebagai penyubur serta pembentuk struktur tanah yang rusak akibat pupuk kimia. Pupuk kandang dapat diterapkan secara langsung baik masih berupa kotoran ternak segar maupun diolah menjadi kompos. Prinsip POK adalah memberikan nutrisi untuk mikroorganisme tanah sehingga bisa bekerja optimal untuk membantu proses penyerapan nutrisi tanaman. Proses fermentasi dalam pembuatan POK ini selama $14-21$ hari. 

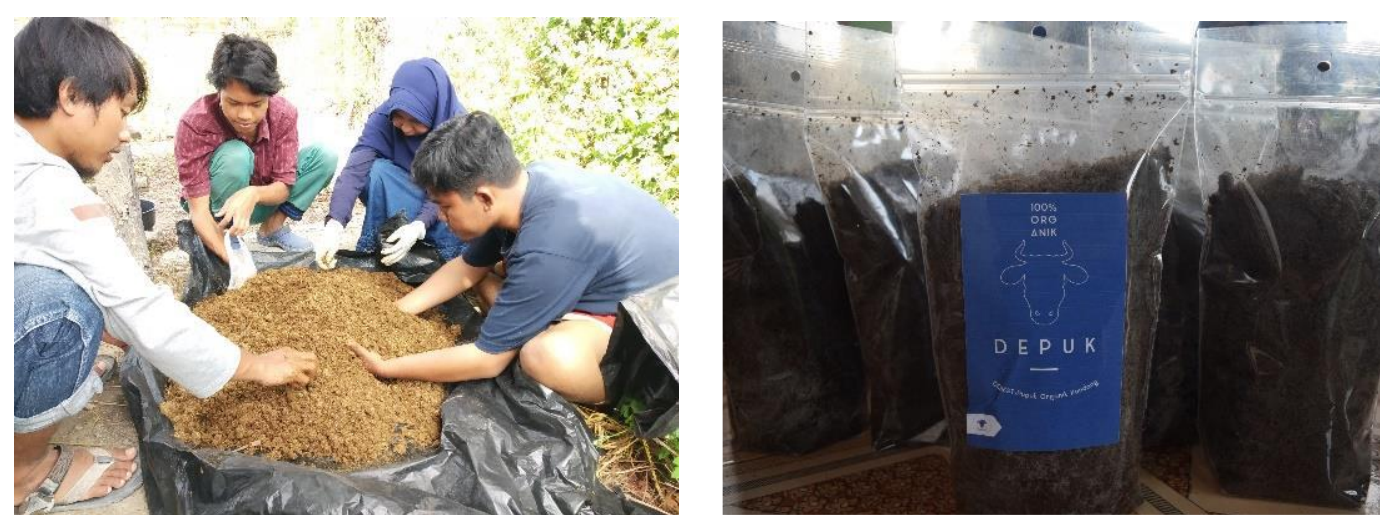

Gambar 7 . Pembuatan POK dan Produk POK

Hasil yang dicapai setelah kegiatan demonstrasi dan pelatihan pembuatan pupuk organik kandang (POK) antara lain masyarakat mengetahui bahwa feses ternak tidak hanya dapat digunakan untuk membuat biogas, namun dapat juga dimanfaatkan untuk membuat pupuk organik yang dapat digunakan untuk menyuburkan tanah dan sebagai pengganti pupuk kimia (buatan pabrik). Masyarakat mengetahui cara pembuatan dan mampu membuat pupuk organik dari limbah/kotoran yang ada disekitar. Pupuk organik yang dihasilkan dapat digunakan untuk memupuk tanaman pangan sendiri sehingga pembelitan pupuk kimia dapat dikurangi/ditekan. Selain itu pupuk organik yang dihasilkan dapat dijual dan menjadi salah satu sumber pendapatan masyarakat maupun dusun/desa.

\section{KESIMPULAN}

Proses pelaksanaan kegiatan telah dilaksanakan sesuai dengan rencana. Proses yang dilakukan mampu membangkitkan minat masyarakat untuk mengadopsi teknologi yang ditawarkan. Hal ini terlihat bahwa 85\% masyarakat yang hadir dalam kegiatan demonstrasi dan pelatihan secara aktif mengikuti rangkaian kegiatan. Selain itu sebagian besar masyarakat telah memahami tema yang menjadi materi dalam kegiatan demonstrasi dan pelatihan.

\section{UCAPAN TERIMA KASIH}

Penulis mengucapkan terima kasih kepada Direktorat Riset dan Pengabdian kepada Masyarakat, Direktorat Jenderal Pendidikan Tinggi Kementerian Ristekdikti yang telah mendanai kegiatan KKNPPM ini. Ucapan terima kasih juga penulis sampaikan untuk aparat desa Serading yang telah membantu dalam berbagai kegiatan selama KKN-PPM berlangsung..

\section{REFERENSI}

Ahmadi, M.R., Sutanto, B., Wijarnako, A.T., Widhiantara, B.W., \& Atmoko, B.W. 2016. Implementasi Sistem Biogas dai Kotoran Hewan Ternak untuk Menanggulangi Kelangkaan LPG dan Meningkatkan Perekonomian Kelompok Tani "Sumber Urip" di Wonogiri.

Andriani, T., Khair, S., \& Hidayatulah, M. 2018. Aplikasi Sensor Pyroelectric Infra Red pada Pengaman Kandang Sapi Kolektif dalam Upaya Optimalisasi Capaian NTB Bumi Sejuta Sapi. INA-Rxiv, 30.

Astika, Glycine, Henni Wijayanti, Siti Hudaidah. 2015 Penambahan Fermentasi Urine Sapi Sebagai Sumber Nutrien Dalam Budidaya Daphnia sp. Jurusan Budidaya Perairan Fakultas Pertanian. Universitas Lampung.

BPS NTB . 2001. Nusa Tenggara Barat dalam Angka. Badan Pusat Statistik Propinsi Nusa Tenggara Barat.

Disnak NTB, Laporan Tahunan Dinas Peternakan Propinsi Nusa Tenggara Barat. 
ICRA. 2001. Towards Sustainable Small-Scale Farming. Research and develeopment options for enhanced integration of cattle in Lowland Irrigated Rice Systems in Lombok Island, Indonesia.

Manan, A., Husain, H. and Winarti, N.K.S., 2015, July. Geographic Information System: Sistem Informasi Embuatan Model Pengendalian Kepemilikan Ternak Sapi Di Wilayah Provinsi NTB. In Seminar Nasional Informatika (SEMNASIF)(Vol. 1, No. 1).

Panjaitan T. 2001. Perbaikan Pemeliharaan Sapi Menunjang Pendapatan Petani dan Daerah NTB. Pojok Teknologi Pertanian. Lombok Post, 21 Agustus. hlm: 6.

Putra, G. M. D., Abdullah, S. H., Priyati, A., Setiawati, D. A., \& Muttalib, S. A. (2017). Rancang Bangun Reaktor Biogas Tipe Portable dari Limbah Kotoran Ternak Sapi. Jurnal Ilmiah Rekayasa Pertanian dan Biosistem, 5(1), 369-374.

Ratnakomala, S. 2015. Menabung Hijauan Pakan Ternak Dalam Bentuk Silase. Biotrends, 4(1), 15-18.

Sembiring H., Wirajaswadi L., Hippi A. Dan Sofyan S. 2001. Evaluasi Penggunaan Bagan Warna Daun untuk Rekomendasi Pemupukan N Padi Sawah.

Simamora, S., \& Salundik, S. W. (2006). Membuat Biogas; Pengganti Bahan Bakar Minyak \& Gas dari Kotoran Ternak. AgroMedia.

Sudiarto, B. 2008. Pengelolaan Limbah Peternakan Terpadu dan Agribisnis yang Berwawasan Lingkungan. Fakultas Perternakan Universitas Padjajaran. Bandung.

Sujana, I., Hardiansyah, G., \& Siahaan, S. (2016). Dukungan Teknologi Pada Integrasi Tanaman Hortikultura-Ternak Sapi Untuk Pengembangan Agribisnis Yang Berkelanjutan. Jurnal ELKHA, 8(2).

Usman, DJ. H. 1999. Kondisi Sapi Potong dan Program Peningkatan Mutu Sapi Potong di NTB. Makalah pada Seminar Produksi Ternak. 